Article

\title{
Unaccompanied Minors: Worldwide Research Perspectives
}

\author{
Esther Salmerón-Manzano ${ }^{1}$ and Francisco Manzano-Agugliaro ${ }^{2, *(\mathbb{D})}$ \\ 1 Faculty of Legal, Social and Human Sciences, Universidad Internacional de La Rioja (UNIR), \\ Av. de la Paz, 137, 26006 Logroño, Spain; esther.salmeron@unir.net \\ 2 Department of Engineering, University of Almeria, ceiA3, 04120 Almeria, Spain \\ * Correspondence: fmanzano@ual.es; Tel.: +34-950-015396; Fax: +34-950-015491
}

Received: 6 December 2018; Accepted: 24 December 2018; Published: 28 December 2018

check for updates

\begin{abstract}
Due to the globalisation of the economy, migratory flows have increased significantly. Unaccompanied foreign minors have become a growing problem in recent years. The objective of this study is to make an analysis from a bibliometric point of view and to identify the main research trends concerning this topic by clusters identification. It has been observed that, above all, there are two main subjects that dominate the scientific literature in this field, the social sciences and medicine. The first one is the clearest in terms of legal and political implications, but the second one is related to the field of determining the age of minors by means of diagnostic tests. As to clusters, the following have been identified: First as a refugee-asylum seeker, second as a refugees-psychology, third as migration, fourth as age determination, and fifth as health care. Finally, the following temporal evolution of the issues dealt with in relation to unaccompanied minors has been observed: War, stress, migration, immigration, risk factors, health, legal aspects and, more recently, vaccination or age determination.
\end{abstract}

Keywords: unaccompanied minors; worldwide research; bibliometric; community detection; refugee; legal aspects

\section{Introduction}

In recent years, thousands of unaccompanied minors have migrated from their countries of birth to European Union countries and the United States. Within the European Union's immigration policy, there is the situation of a group of persons who require special protection, and whose legal regulation has certain loopholes in it [1]. They are underage immigrants (UAM) who arrive in community territory illegally and unaccompanied by an adult [2]. Given their illegal situation, there is the problem of what to do with them when they arrive on community territory without accompaniment, given the fragility and lack of protection of these people. Well, it is a fact that minors, alone or accompanied, can also be repatriated if a member of their family, or their guardian, or a reception centre or appropriate reception services in the State of return receives them on arrival [3].

But what are these children's reasons for migrating without the protection of an adult? In the 19th century, voluntary massive migrations began so people with now higher economic expectations could improve their quality of life. At the end of the 19th century, it was Europeans with a poor economic situation who emigrated in increasing numbers, to South America, with Argentina and Brazil especially being the preferred destination of European emigrants [4]. However, it was only a century later that the low-income population from the Third World countries migrated to industrialised countries, where the ageing of the population generated a demand for immigrants, which reinforced emigration. In addition, there was a considerable increase in the number of migrants from Europe, from countries such as Italy and Eastern Europe, due to the industrial revolution. 
In a first stage of massive influxes of immigrants, international migrations took place in a context where there was little control of people, which changed after the Second World War [5], when mechanisms were established to control and identify immigrants, such as visas, immigrant quotas or security barriers. At the beginning of the 19th century, Europe was the target of a massive influx of immigrants from Asia, Africa, and the Middle East. These countries had not generated a considerable number of immigrants to European countries some years before. This was due, partly, to the lower cost of transport and to the difficult situation in these countries when the economic level of the people was low. Another factor that influenced this was the spread of the welfare state in third countries that people in Europe could enjoy, thanks to social networks and the Internet. However, the phenomenon of immigration of foreign minors unaccompanied by an adult relative is relatively new in countries such as Spain, or Italy [6], as well as in the European Union, and can be traced back to just before the last decade of the 19th century.

To define unaccompanied foreign minors, we use UNICEF's 2009 definition, according to which, an unaccompanied foreign minor is "A minor who is a national of a non-EU Member State or a stateless person under 18 years of age who, on entering Spanish territory, is not accompanied by an adult". An unaccompanied foreign minor is also an unaccompanied minor if he or she is left alone after entering the territory of a Member State of the European Union, in this case in Spanish territory [7].

Countries with a strong tradition of migration began to perceive this type of migration from the 1990s onwards, although there were already problems with the reception of minors after the Second World War, when millions of refugee children fled central Europe and sought asylum in countries such as the United Kingdom [5]. Nowadays, countries bordering or close to Africa are the ones that have this problem, such as Spain or Italy. In Spain, as an example, this phenomenon began to be detected in 1996, initially in the Canary Islands, when the first boat with minors on board from Africa was intercepted. After the year 2000, there was a boom in the number of minor immigrants without family members. However, the public administrations were not prepared for this new migration phenomenon, where the caseload was very extensive and the problems that could arise from this were rather varied.

The Stockholm Programme 2010-2014 set among its objectives to develop a comprehensive European migration policy based on solidarity and responsibility, combating illegal immigration and preventing traffic in human beings [8]. It therefore suggests the implementation of a Community action plan to facilitate cooperation with the countries of origin and includes measures for prevention, protection, and return assistance [9].

The Stockholm Programme 2010-2014 aimed to harmonise the situation in European countries with policies for the integration of immigrants. It enhanced cooperation with the countries of origin and transit of immigrants to their final destination, and with job prospects and social protection in order to achieve the development of a comprehensive European migration policy in a globalised and forward-looking world based on solidarity [10].

Europe, with a clearly ageing population [11], will continue to need immigrants, but it must encourage them to arrive legally and with the aim of working. For this reason and given that the Community immigration policy is characterised by the relationship between immigration (itself) and the labour market, the Stockholm Programme aims to progress in the fight against illegal immigration and to prevent human trafficking from reaching Community territory illegally.

For this reason, and with a view to this group of specially protected immigrants, such as unaccompanied minors, the aim is to implement an action plan at a Community level to promote cooperation with the countries of origin, including measures for prevention, protection, and return assistance [12]. There is also a need to establish a common asylum protection area, based on a common asylum procedure and a similar status for all persons to whom international protection is granted [13]. 
The Stockholm Programme compiles some of the aspects that the European Pact on Immigration and Asylum also covered, such as the fight against illegal immigration and the creation of a single framework for the reception of immigrants [14].

In addition, Directive 2008/115/EC of the European Parliament and of the Council of December 2008 on standards and procedures in Member States for returning illegally staying third-country nationals, or Return Directive, transposes the principle of non-refoulement for illegal immigrants whose life or liberty is at risk in their countries of return [15]. Nevertheless, it allows the expulsion and repatriation of unaccompanied minors arriving in Community territory, if they are received by their family or guardian or by a reception centre on their return to their country of origin $[16,17]$.

For these reasons, unaccompanied foreign minors have been the subject of research, study, and publication, and it is of great interest to identify such publications, their subject matter, as well as the trend and evolution of the issues dealt with, in accordance with international conflicts and migration flows. Therefore, the aim of this paper is to study the research trends worldwide concerning unaccompanied minors, given the many scientific facets that may relate to unaccompanied minors' policies and rights.

\section{Materials and Methods}

The methodology used in this study was to conduct a complete search of Elsevier's Scopus database, using a search string to search the subfields of: Title, abstract, and keywords, to identify publications addressing the issue of unaccompanied minors. The search was limited to the last 30 years, i.e., from 1987 to 2017. The query string was: TITLE-ABS-KEY ("unaccompanied minors" or "unaccompanied children" or "unaccompanied adolescent"), since English literature mainly includes these three types of meanings for children.

This methodology has been used successfully in other bibliometric studies [18-20]. Publications referring to unaccompanied minors were evaluated based on the following aspects: Evolution of scientific production by year, type of publication, language, distribution of publications by country, categories of publication indexation, and keyword analysis by the authors.

Detection of networked communities is one of the most popular topics in modern science [21]. Communities, or clusters, are often groups that are more likely to be connected to each other than to members of other groups, although other possible patterns may exist [22]. Identifying communities is an interesting problem in our case, as it indicates the main themes around which the publications are grouped. For this analysis, a download of the keywords of each publication is undertaken separately, generating a line of file with up to 6 keywords used in each work. This file is introduced into a network analysis software, which will detect the main communities. The Vosviewer has been used in our work (http:/ / www.vosviewer.com/), developed specifically for this type of analysis of scientific production [23]. The last part of the analysis of the results was to apply the detection of communities to identify the clusters around which the research is grouped. Lastly, this analysis of communities was discussed in a temporal sense, in order to analyse how the themes have evolved in recent years, that is, to establish research trends [24]. Figure 1 shows a flow chart of the methodology used. 


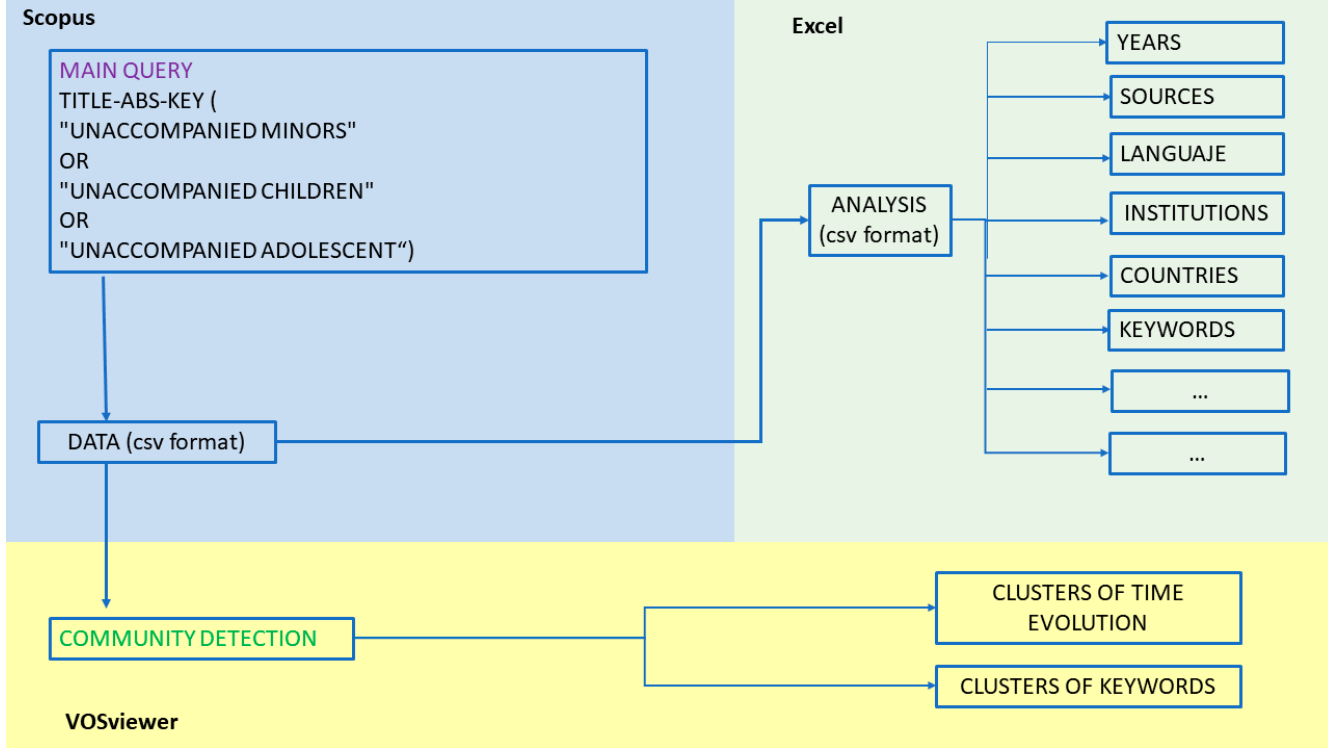

Figure 1. Flow chart of the methodology.

\section{Results}

\subsection{Evolution of Scientific Production}

The search of the publications on this subject in the Scopus database showed 360 results, the temporal distribution of which is shown in Figure 2. It can be observed that the scientific interest of the topic under research could be qualified as low and stable in the first 20 years, from 1987 to 2007 , and since then, a fluctuating but ascending growth emerges, which can be considered exponential from 2013 onwards.

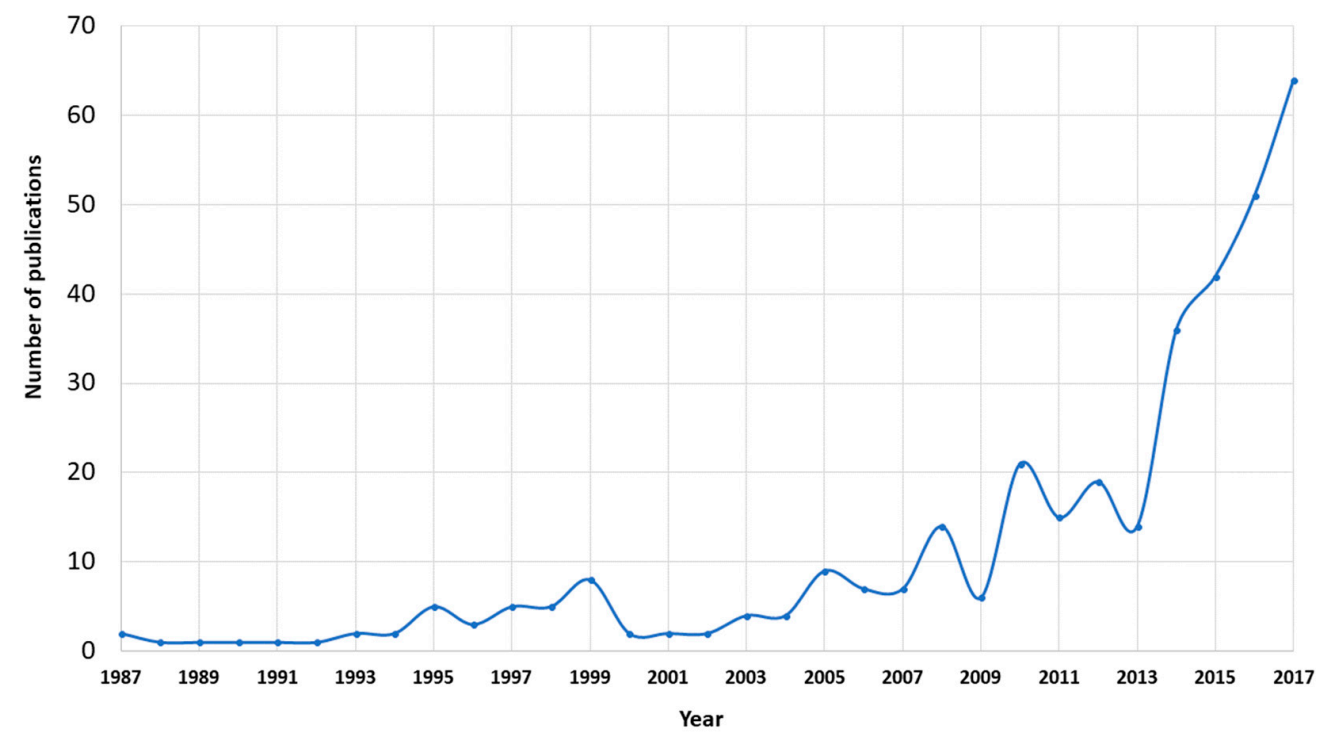

Figure 2. Evolution of scientific production in the last 30 years in relation to unaccompanied minors.

This may be due to the large increase in political asylum seekers in the European Union in 2013, as appears in the preamble to the European Commission's 5th Annual Report on Migration and Asylum (2013), which states that: "The year 2013 saw a much larger increase in the number of asylum requests than we had known for several years" [25]. From this same report, we extract the data that: "The total number of asylum requests in 2013 was 434,160, which is a significant increase, an increase of about 100,000 over the previous year". 
The number of unaccompanied minors seeking international protection remained the same as in 2012, with 12,425 applications, mainly from Afghanistan (3310), Somalia (1580), Syria (1010), and Eritrea (715). Most of these were accepted in Sweden, Germany, the United Kingdom, Austria, and Italy which, as will be seen below, are related to this research.

In ending this report on the subject under discussion, it highlights that "Unaccompanied minors are a vulnerable group that continued to receive a great deal of attention in 2013, focusing equally on asylum-seekers and non-asylum-seekers. In September 2013, the European Parliament adopted a resolution about unaccompanied minors in the EU, urging the Commission and the Member States to step up their efforts to protect this vulnerable group. EASO continued its work on age assessment, search for their family and countries of origin" [25].

\subsection{Types, Languages of Publications, and Sources}

In the analysis of the scientific publications, in general, the most widely used media are articles in journals, as in our case, where articles $(77 \%)$ and reviews $(7 \%)$ account for $84 \%$ of the total; the high number of articles with the nature of review articles (reviews) accounting for $7 \%$ of the total is relevant data. But it is striking that, unlike other scientific fields, where conferences are the second most important source of information (Hernandez-Escobedo et al., 2018), books and book chapters are the most important source of information on the subject (of unaccompanied minors). Figure 3 shows in percentage terms how the scientific production about unaccompanied minors is distributed.

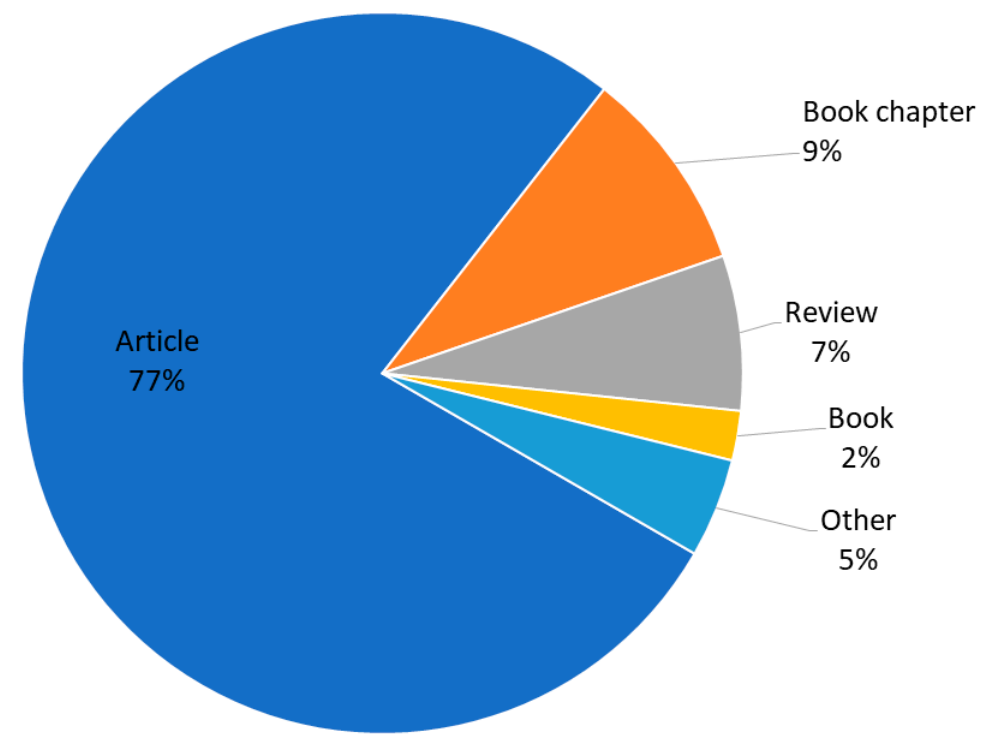

Figure 3. Type of scientific production on unaccompanied minors in the last 30 years (1987-2017).

Regarding the language in which the international scientific publication is written, it is usually English, as expected, and this case is no exception (Figure 4). However, what is striking is that there are other languages with a significant percentage, or even some that are not internationally relevant, given their relationship with the issue of receiving refugees: German, Spanish, French, Portuguese, Italian, Danish or Hebrew. The latter is due to the high number of immigrants coming to Israel from Africa.

Table 1 lists the main journals that publish on the subject under study. In terms of the number of publications $(\mathrm{N})$ of this topic, the ranking is led by Social Work and Society followed by Children and Youth Services Review. In order to make a comparison from a bibliometric point of view, the year 2017 has been selected because it is the last one with complete data. There are two journals that publish more than 200 articles a year, the International Journal of Legal Medicine and Children and Youth Services Review. One of the most widespread bibliometric indicators is the number of citations received for articles published in a specific journal. In this sense, three journals stand out that in 2017 received more than 4000 citations: Children and Youth Services Review, International Journal of Legal Medicine, and Journal 
of Ethnic and Migration Studies. The highest Citescore is: International Journal of Legal Medicine and Journal of Ethnic and Migration Studies, which are also the journals that have the highest SJR (SCImago Journal Rank is a measure of scientific influence of scholarly journals that accounts for both the number of citations received by a journal and the importance or prestige of the journals where such citations come from). However, Source Normalized Impact per Paper (SNIP) measures contextual citation impact by weighting citations based on the total number of citations in a subject field), if the SNIP is used, the best placed is the Journal of Refugee Studies. Finally, with respect to the percentage of works not cited, it is found that the International Journal of Refugee Law has the highest percentage, with almost $62 \%$, and in the opposite extreme, with $29 \%$, would be the International Journal of Legal Medicine, probably due to the topics covered by the journals, as it is known that issues related to medicine have high rates of citations.

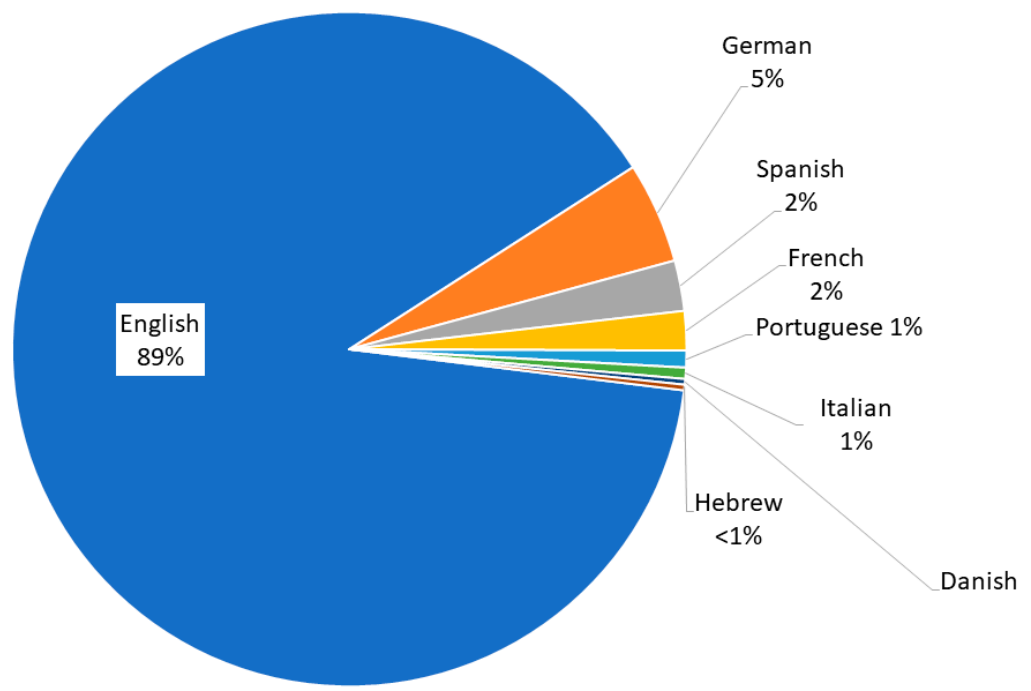

Figure 4. Languages of scientific production.

Table 1. Main journals and their indicators.

\begin{tabular}{|c|c|c|c|c|c|c|c|}
\hline Source Title & $\mathbf{N}$ & Ntot & $\begin{array}{c}\text { CiteScore } \\
(2017)\end{array}$ & $\begin{array}{c}\text { SJR } \\
(2017)\end{array}$ & $\begin{array}{l}\text { SNIP } \\
(2017)\end{array}$ & $\begin{array}{c}\text { Citations } \\
(2017)\end{array}$ & $\begin{array}{c}\text { \% Not Cited } \\
\text { (2017) }\end{array}$ \\
\hline Social Work and Society & 17 & 24 & 0.22 & 0.132 & 0.18 & 50 & 45.83 \\
\hline International Journal of Refugee Law & 10 & 26 & 0.63 & 0.389 & 0.748 & 453 & 61.54 \\
\hline Child and Family Social Work & 9 & 180 & 1.66 & 0.941 & 1.38 & 1701 & 29.44 \\
\hline Journal of Ethnic and Migration Studies & 8 & 193 & 2.11 & 1.486 & 1.761 & 4267 & 26.94 \\
\hline International Journal of Legal Medicine & 7 & 237 & 2.21 & 1.21 & 1.25 & 4606 & 29.54 \\
\hline Childhood & 6 & 40 & 1.53 & 0.894 & 1.611 & 1475 & 42.5 \\
\hline International Migration & 6 & 93 & 1.28 & 0.887 & 1.118 & 1932 & 55.91 \\
\hline
\end{tabular}

\subsection{Distribution of Publications by Country}

The main countries concerned by this issue, as reflected in their scientific output, are, in order: The USA, the UK, Germany, Sweden, Norway, Italy, Belgium, Spain, Australia, Canada, the Netherlands, and Sweden. It is to be expected that the countries with the greatest concern are those that receive unaccompanied minors, although there is also a certain sensitivity towards countries of origin, especially in the areas of departure, such as Mexico to the USA [26] or from Central America through Mexico [27], sub-Saharan Africa (countries such as Eritrea, Kenya, Congo, Mauritania, Tanzania, Uganda, Zimbabwe) to Europe [28], and Asian countries (countries such as Thailand or Malaysia) to Australia $[29,30]$. Figure 5 shows a world map of countries with scientific production in this area. 


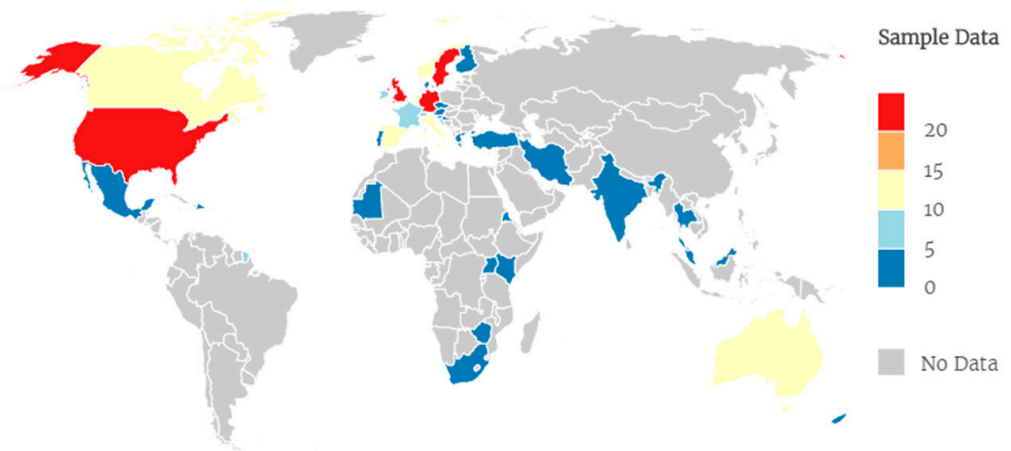

Figure 5. Geographical distribution by country of scientific production in relation to unaccompanied minors.

\subsection{Distribution into Thematic Categories}

The thematic categories into which the scientific work is classified show the approaches from which the problem under study is analysed. In the case in point, Figure 6, it can be observed that, mainly, it is the social sciences in which the field of Law and Legislation is included, with $42 \%$ of the publications; but it is observed that it is a rather multidisciplinary subject, since it involves aspects such as Medicine (27\%), Psychology (14\%), Arts and Humanities (7\%) and, finally, in small proportions of 2\%, (fields such as) Nursing, Environmental Sciences or Biochemistry, Genetics and Molecular Biology, the latter being the field dedicated to genetic tests for the diagnosis of age [31].

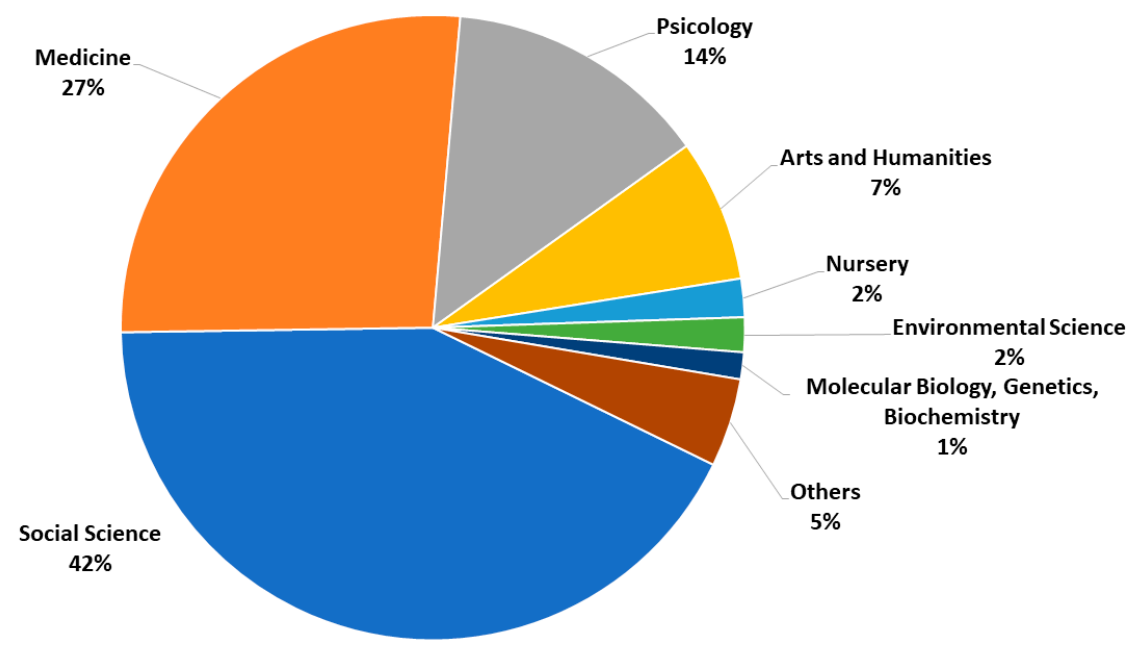

Figure 6. Distribution of scientific production in relation to unaccompanied minors by thematic category.

\subsection{Analysis of Author Keywords and Index Keywords}

Keyword analysis identifies or summarises the work of researchers. Figure 7 shows a cloud word where size and centrality indicate the importance of this keyword in the total number of publications, that is, the number of times it is repeated. It can be seen that the central issue is that of refugees. Additionally, the variants of the search term are highlighted: "Minors", "child", "adolescents", "children", etc. Finally, there are those related to asylum: "Asylum seeker", "asylum", or "asylum seekers".

Another large group of keywords are those used for age determination, which, in order of importance of their occurrence, are: "Age determination", "age", "age determination by teeth", "age determination by skeleton", "age estimation", "age factors", "age assessment", "age distribution", "aged". It should be clarified that age determination has many/different legal repercussions and, therefore, an informed consent must be obtained from the individual and/or his or her representative prior to age assessment. 


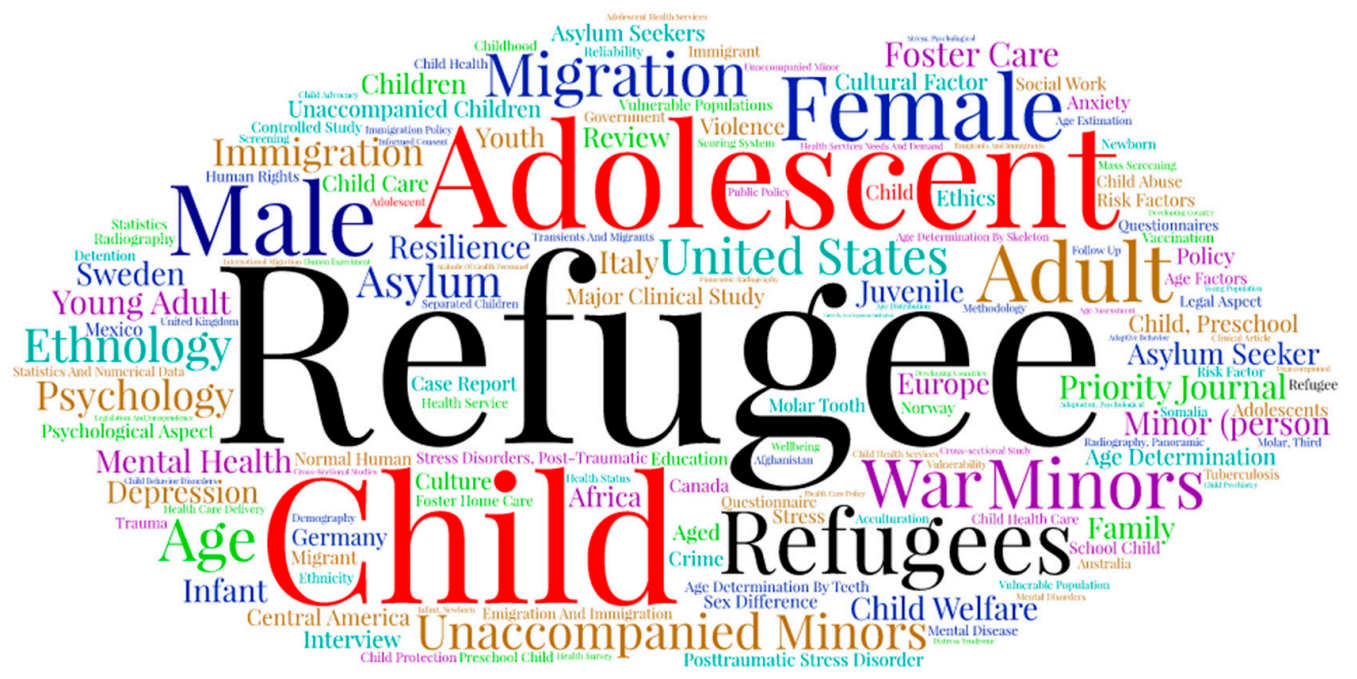

Figure 7. Cloud of words with keywords used in unaccompanied minors' work.

In particular, studies related to post-traumatic stress and psychology occupy relevant positions: "Stress disorders, post-traumatic", "posttraumatic stress disorder", "psychology", "psychological aspect", "adaptation, psychological", and "stress, psychological". Furthermore, the issue of what to do with these children appears as a middle concern in these publications: "Child", "preschool", or "foster care".

If a temporal analysis of the main keywords is carried out (see Figure 8), it can be seen that these become relevant from 2013 onwards. For this purpose, the grouping of the following keywords has been taken into account as a single group: "Asylum", "asylum seeker", "asylum seekers", and "asylum-seekers". It can be observed that there is a slight tendency to decrease the issue of "refugee" and increase the "asylum", the latter keyword especially since 2015. With respect to gender issues (male/female), it is observed that they go in parallel and even in the last year the number of works that address this subject are equal. On the issue of the age of unaccompanied minors, there are the terms "child" and "adolescent", and it is noted that in the years 2013 to 2015, there were more papers on adolescents, and since then, there is a bigger number of papers related to "child". The latter could be indicative of the decreasing age of unaccompanied minors.

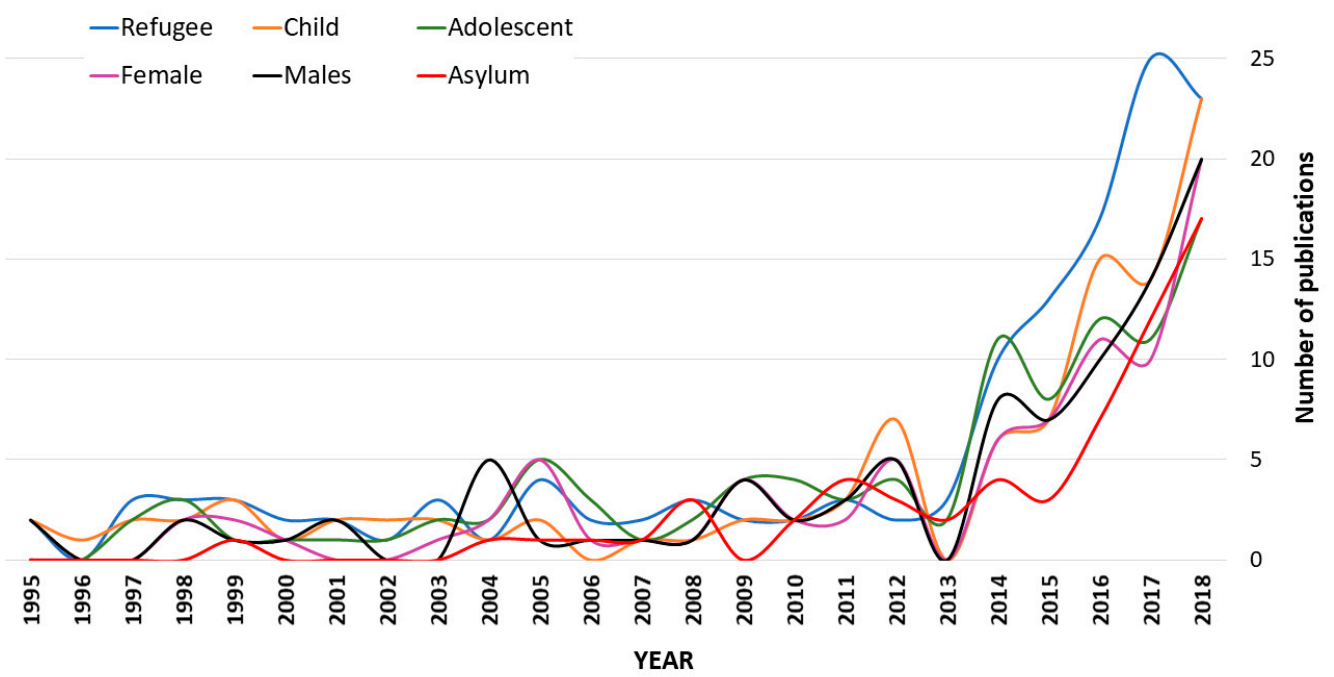

Figure 8. Temporal evolution of the main keywords. 
Table 2 shows the main keywords used in the countries with the highest number of publications on the subject of unaccompanied minors. As can be observed, in the first 5 countries, which are the USA, the UK, Germany, Sweden, and Norway, their main keywords are "refugees", associated with "asylum", "age determination" or "health problems" [32,33]. The following countries (Italy and Belgium) have "age determination" as their main keyword, especially in Italy, where the three keywords revolve around this issue. The eighth country, Spain, has a different vision of the issue, and it is this type of detention and the treatment that follows it to the individual, and the administrative reform in this area where there are proposals such as the need for a common protocol in Europe on the detention of unaccompanied foreign minors [34]. The latest countries analysed, Australia, Canada, and the Netherlands, return to the issue of refugees. There are therefore three trends: That of refugees for Anglo-Saxon countries, that of age determination for Mediterranean countries, and that of Spain in the form of detention and associated policies.

Table 2. Main keywords of the countries with the greatest scientific interest in unaccompanied minors.

\begin{tabular}{llll}
\hline \multirow{2}{*}{ Country } & \multicolumn{1}{c}{ Main Keywords Used } \\
\cline { 2 - 4 } & \multicolumn{1}{c}{ 1st } & \multicolumn{1}{c}{ 2nd } & 3rd \\
\hline USA & Refugees & Ethnology & Major Clinical Study \\
UK & Refugees & Asylum & Mental Health \\
Germany & Refugees & Minor (person) & Age Determination \\
Sweden & Refugees & Asylum Seeker & Immigration \\
Norway & Refugee & Depression & Mental Health \\
Italy & Age Determination & Age Determination by Teeth & Age Estimation \\
Belgium & Age Determination by Teeth & Asylum & Care \\
Spain & Detention & Inhuman or Degrading & Migration/Administrative Reform \\
Australia & Refugee & Treatment & Child Welfare \\
Canada & Child Welfare & Asylum Seeker & Asylum Seeker/Immigration Policy \\
Netherlands & Refugee & Refugee & Controlled Study \\
\hline
\end{tabular}

Within the keywords, there is a group of them dedicated to countries or geographical areas which undoubtedly relate to the origin or destination of unaccompanied minors. Table 3 shows, in order of importance of appearance, these locations. It is noted that, in general, destinations occupy positions of greater importance than those of origin, but within a partnership between them: i.e., United States-Central America; Germany/Europe/Italy-Africa; United Kingdom-Afghanistan, Canada-Mexico.

Table 3. Geographical areas of origin or destination reflected in the keywords.

\begin{tabular}{ccc}
\hline Interest & Geographical Area & Origin/Destination \\
\hline 1 & United States & Destination \\
2 & Central America & Origin \\
3 & Germany & Destination \\
4 & Europe & Destination \\
5 & Africa & Origin \\
6 & Italy & Destination \\
7 & United Kingdom & Destination \\
8 & Afghanistan & Origin \\
9 & Australia & Destination \\
10 & Canada & Destination \\
11 & Mexico & Origin \\
12 & Norway & Destination \\
13 & Somalia & Origin \\
\hline
\end{tabular}


Once the main countries studying the issue of unaccompanied minors have been analysed, it is appropriate to study the main institutions that address the issue. Thus, we find that the first 10 institutions are those of Table 4, which also includes the main keywords that address their scientific works. In general, the keywords are the same as those analysed for the countries, but it is remarkable that the first three institutions have between them their own country as a keyword, so the relationship is as follows: Stockholms Universitet/Sweden, Universiteit Gent/Belgium, University College Dublin/Ireland. In the fourth place, there is a change in this sense and it is to study one of the sites of origin of migration, so the New York University is interested in Central America. It has been observed that the mainstream is that of most publications in this field, focusing on "asylum seeker" or "refugee". But apart from that, there are basically two points of view, that of the "foster care", for example of the Universiteit Gent [35], University College Dublin [36], or Boston College [37], and those of intersectoral analysis, such as those of the Universiteit Gent [38,39].

Table 4. Main affiliations and their most relevant keywords in the subject of unaccompanied minors.

\begin{tabular}{llll}
\hline \multicolumn{1}{c}{ Institution } & \multicolumn{1}{c}{ Main Keywords Used } \\
\cline { 2 - 4 } & \multicolumn{1}{c}{ 1st } & \multicolumn{1}{c}{ 2nd } & 3rd \\
\hline Stockholms Universitet & Human & Sweden & Asylum Seeker/Refugee \\
Universiteit Gent & Belgium & Care & Humanitarianism/Intersectionality \\
University College Dublin & Foster Care & Asylum Seeker & Ireland/Resilience \\
New York University & Female/Male & Central America & Cultural Factor/Ethnology \\
Centers for Disease Control and & Adolescent & Human & Ethnology \\
$\begin{array}{l}\text { Prevention } \\
\text { Charité-Universitätsmedizin Berlin } \\
\text { Boston College }\end{array}$ & Human & Adolescent & Refugee \\
Harvard Medical School & Child & Foster Care & Immigration/ Refugee \\
Universitetet i Oslo & Human/Male & Human & Refugee \\
King's College London & Adolescent/Human & Child & Posttraumatic Stress Disorder \\
\end{tabular}

\subsection{Analysis of the Interconnection among Keywords: Detection of Communities}

Within the analysis of the interconnection/relationship among keywords, five communities have been detected. They are represented in Figure 9 in different colours. Table 5 shows the characteristics of these clusters. In order to see the complete relation among the different clusters detected, Figure 9 has been elaborated, where each node is represented as a neuronal network, the keyword, and the thickness of the link between nodes as the frequency of this relation.

Cluster 1 is the most extensive, with $23.3 \%$ of keywords, and also with regard to countries they represent. It focuses on the issue of refugees and asylum seekers. The geographical areas of origin are Central America or Mexico, and the destination ones are Australia, Canada, Europe, the Netherlands, Sweden, and the UK. Cluster 2 is the second most important, with $22.7 \%$. It also focuses on the issue of refugees, but mainly on psychological aspects, e.g., post-traumatic stress disorder or depression. In this case, only Norway is listed as a geographical area. Cluster 3 is the third most important, with $18.8 \%$. The issues studied are related to emigration and immigration or international migration. This cluster is dominated by the USA as a geographical area, although other areas, such as Sudan or Africa, also appear. Cluster 4 is dominated by a very specific age determination problem. Italy is the geographical area that (most) studied this problem, as was also observed before, when its main keywords were studied. Finally, Cluster 5 is the one focused on the German problem. Apart from the demands for asylum, the health issue, such as including infectious diseases, health and paediatric issues, are also studied. 


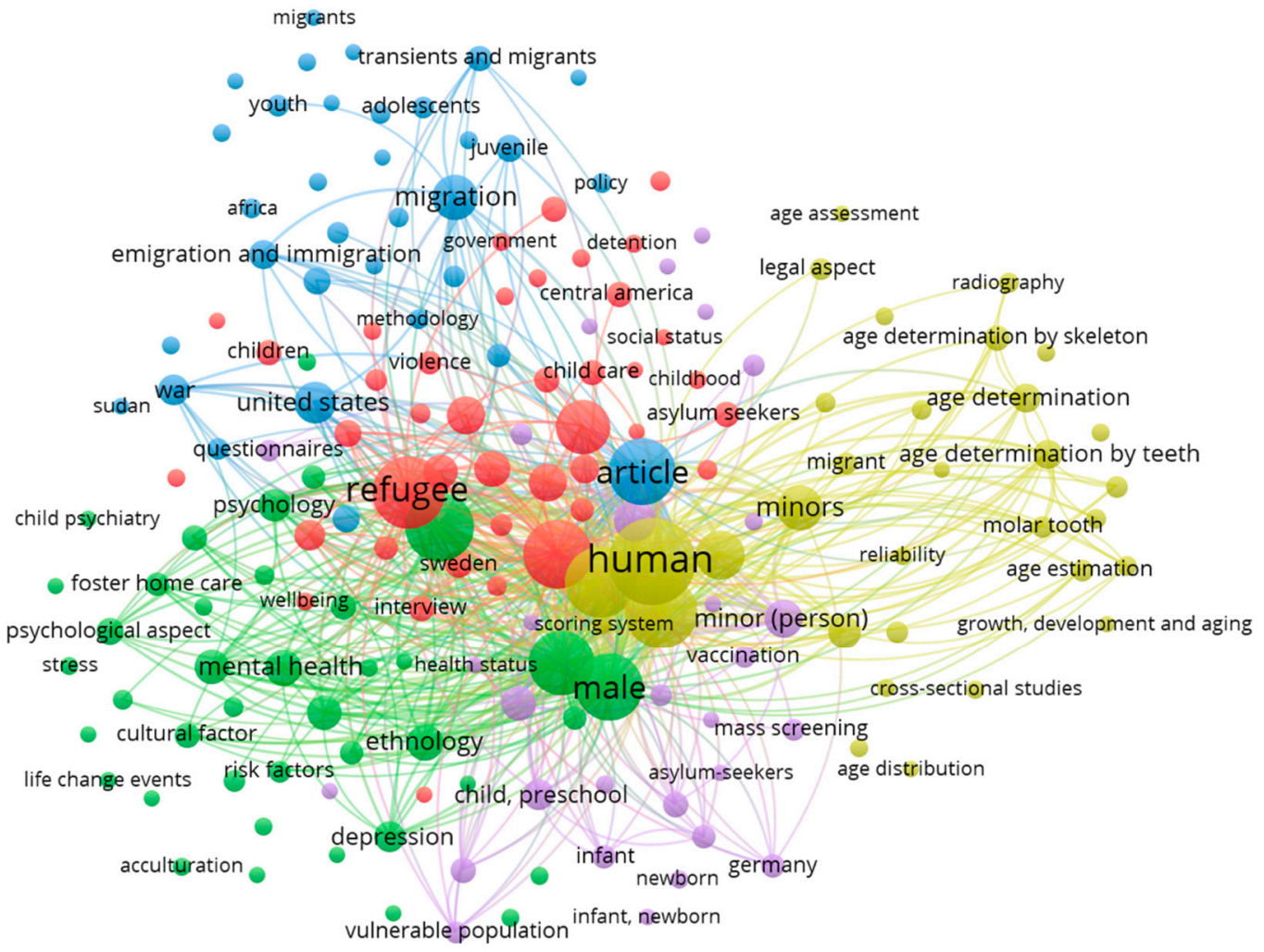

Figure 9. Analysis of keywords used in unaccompanied minors' works: Relationships among them and clusters.

Table 5. Clusters detected in the field of unaccompanied minors.

\begin{tabular}{|c|c|c|c|c|c|}
\hline Cluster & Colour & Keywords & Countries (Keyword) & Name & $\%$ \\
\hline 2 & Green & $\begin{array}{l}\text { Refugees, psychology, psychological } \\
\text { aspect, mental health, ethnology, } \\
\text { depression, male, female, post-traumatic } \\
\text { stress disorder, sex factor }\end{array}$ & Norway & Refugees-Psychology & 22.7 \\
\hline 3 & Blue & $\begin{array}{l}\text { United States, migration, education, } \\
\text { child abuse, international migration, } \\
\text { war, health service, vulnerability, } \\
\text { emigration and immigration }\end{array}$ & $\begin{array}{l}\text { The United States, Sudan, } \\
\text { Africa }\end{array}$ & $\begin{array}{l}\text { Emigration and } \\
\text { immigration }\end{array}$ & 18.8 \\
\hline 4 & Yellow & $\begin{array}{l}\text { Age assessment, age determination, age } \\
\text { estimation, grow development and } \\
\text { aging, minors, molar tooth, third molar, } \\
\text { legal aspect, radiography }\end{array}$ & Italy & Age determination & 18.2 \\
\hline
\end{tabular}

If the temporal issue is considered (see Figure 10), an evolution can be observed from issues such as war, stress, migration or immigration, to risk factors, health, legal aspects, and finally, other more recent groups of words, such as vaccination and age determination (by skeleton, by teeth, etc.). The first war-related work in this field, for example, was carried out in countries such as Mozambique [40] in 1993, in 1994 in Cambodia [41], in 1995 in Eritrea [42] or Rwanda [43]. Regarding risk factors, especially with regard to mental health, they appeared in 2002 [44] and 2004 [45]. Regarding the issue of age determination, although there is work (available) from 1999 on legal aspects [46], medical works started in 2006 [31,47] and 2008 [48]. 


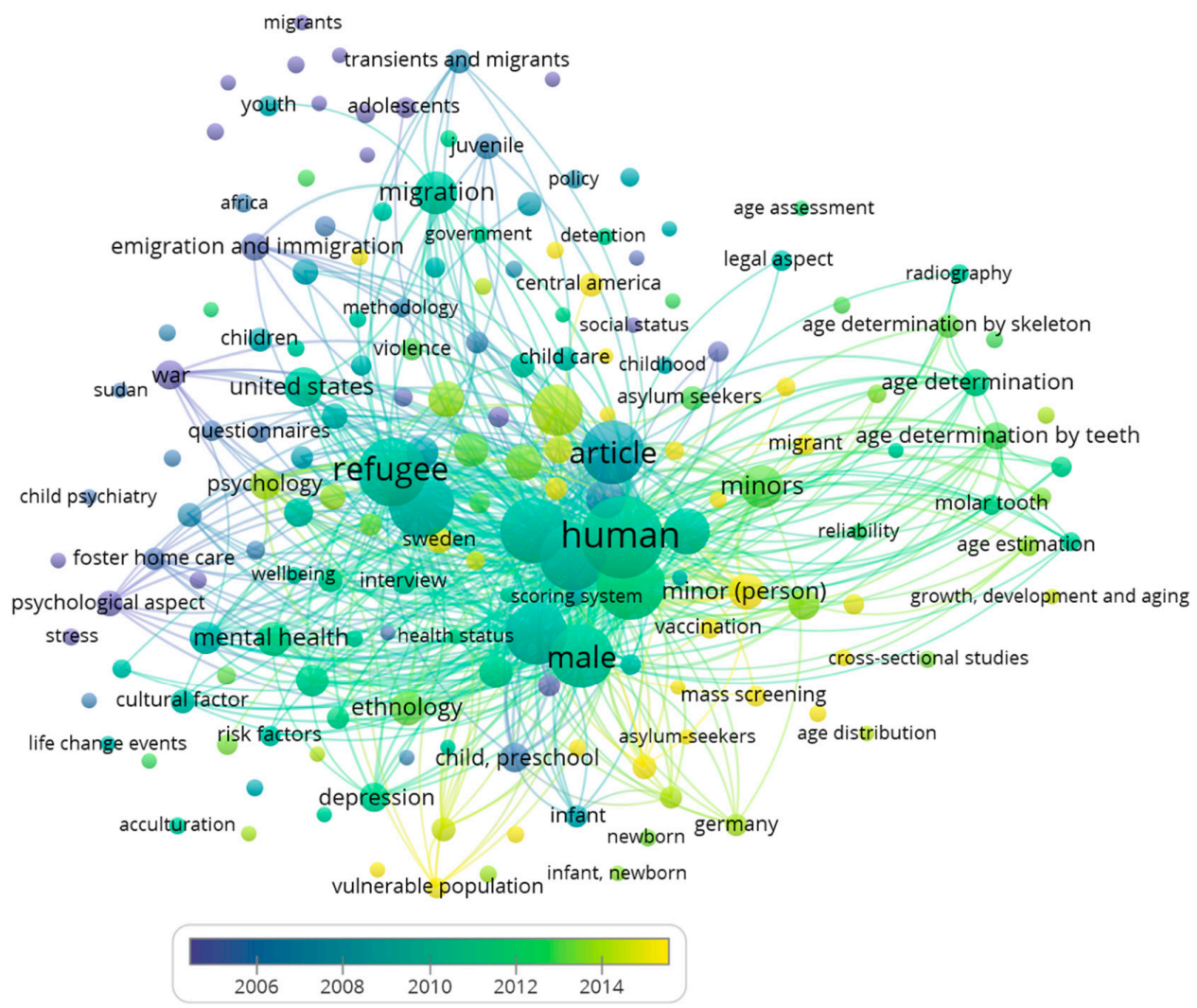

Figure 10. Time evolution of keyword groups on unaccompanied minors' work.

\section{Discussion}

When there is doubt about the age claimed, age assessment is necessary to determine whether a person is an adult or a child. While knowing one's age may be obvious to those of us living in Europe, UNICEF statistics show that only half of children under 5 years of age have their births registered in the developing world [25]. Children may arrive without identity or residence documents establishing their identity and age (years). In addition, it is known that the authenticity of the documents they carry is questionable and/or may not be considered enough proof of age [25]. It should be remembered that the United Nations Convention on the Rights of the Child defines a child as every human being below the age of 18 years in its Article 1, unless the law applicable to the child provides for a majority before the child is born [49].

Knowing someone's age and identity is therefore important, as it determines whether and for how long one will be qualified for the specific rights of the child provided for in the convention, as well as the relevant national legislation [50].

It should be clarified that an informed consent must be obtained from the individual and/or his or her representative prior to the commitment to age assessment [51]. They should be informed of the possibility that their age may be determined by medical examination. For the individual to make an informed decision on whether to consent to a medical examination, information should be provided on the method, including possible consequences of the result of the examination, as well as the consequences of the individual's refusal to undergo a medical examination. Such information must be provided free of charge, and be provided in a language they understand, or which can reasonably be expected to understand.

However, as far as the social sciences are concerned, it seems that global research focuses more on the dimension of legal and policy implications. Despite them, it is necessary to highlight some studies that, although they imply political implications, start from the point of view of the minors and of how they approach the acculturation process and the educational interventions that are proposed to them 
in the host country [52]. Thus, from the social point of view, there is not much work on intervention models regarding the care process or the specific needs of these adolescents in terms of education, health, housing, transition to adulthood life, and social support [53].

\section{Conclusions}

In this work, the scientific publications on unaccompanied minors have been analysed from a multidisciplinary point of view, noting that, from 2013 onwards, the increase in these publications was exponential, coinciding with the fact that, during this year, there was an increase in the number of asylum applications in the European Union. Additionally, it is a field of study where the countries of destination are mainly involved, but there is also concern on the part of some countries of origin. The main countries contributing to this field are, according to the number of publications: The USA, the UK, Germany, Sweden, Norway, Italy, Belgium, Spain, Australia, Canada, the Netherlands, and Sweden. It has been observed that above all, there are two major disciplines that govern the scientific literature in this field, namely the social sciences and medicine, the first being the clearest in terms of legal and political implications, but the second being the field of determining the age of minors by diagnostic tests. Knowing the age of the alleged child is important as it determines whether and for how long the child will have specific rights under the international convention on the rights of the child, as well as relevant national legislation. Regarding the countries of destination or reception of minors, three research trends have been observed: That of refugees for Anglo-Saxon countries, that of age determination for Mediterranean countries, and that of Spain regarding the form of detention and associated policies. Within the international scientific communities, the following ones have been identified, grouped around the themes of: First as refugee-asylum seeker, second as refugees-psychology, third as emigration and immigration, fourth as age determination, and fifth as heath care. This work concludes that, overall, the countries of destination are more concerned than the countries of origin about these unaccompanied minors. Furthermore, there is a need for common directives in the European Union on the arrival of unaccompanied foreign minors, although, as has been shown, the problems of the countries of destination are significantly different, probably due to the huge amount and origin of these unaccompanied minors.

Author Contributions: E.S.-M. and F.M.-A. conceived and designed the search and wrote the paper.

Funding: This research received no external funding.

Acknowledgments: The authors would like to thank to the CIAIMBITAL (University of Almeria, ceiA3) for its support.

Conflicts of Interest: The authors declare no conflict of interest.

\section{References}

1. Boswell, C. The political functions of expert knowledge: Knowledge and legitimation in European Union immigration policy. J. Eur. Public Policy 2008, 15, 471-488. [CrossRef]

2. Barbulescu, R.; Grugel, J. Unaccompanied Minors, Migration Control and Human Rights at the EU's Southern Border: The role and limits of civil society activism. Migr. Stud. 2016, 4, 253-272. [CrossRef]

3. Parusel, B. Unaccompanied Minors in Europe: Between immigration control and the need for protection. In Security, Insecurity and Migration in Europe; Lazaridis, G., Ed.; Ashgate: Farnham, UK, 2011; pp. 139-160.

4. Massey, D.S. The social and economic origins of immigration. Ann. Am. Acad. Polit. Soc. Sci. 1990, 510, 60-72. [CrossRef]

5. Androff, D. The human rights of unaccompanied minors in the USA from Central America. J. Hum. Rights Soc. Work 2016, 1, 71-77. [CrossRef]

6. Rania, N.; Migliorini, L.; Fagnini, L. Unaccompanied migrant minors: A comparison of new Italian interventions models. Child. Youth Serv. Rev. 2018, 92, 98-104. [CrossRef] 
7. United Nations Children's Fund (UNICEF). Handbook on the Optional Protocol on the Sale of Children, Child Prostitution, and Child Pornography; Innocenti Research Centre: Florence, Italy, 2009. Available online: http:/ / www.unicefirc.org/publications/pdf/optional_protocol_eng.pdf (accessed on 15 September 2018).

8. Carmel, E. European Union migration governance: Utility, security and integration. Migration and Welfare in the New Europe. Soc. Protect. Challenges Integr. 2011, 49-66. [CrossRef]

9. Kaunert, C.; Occhipinti, J.D.; Léonard, S. Introduction: Supranational governance in the Area of Freedom, Security and Justice after the Stockholm Programme. Camb. Rev. Int. Aff. 2014, 27, 39-47. [CrossRef]

10. Kaunert, C.; Léonard, S. The European Union asylum policy after the Treaty of Lisbon and the Stockholm Programme: Towards supranational governance in a common area of protection? Refugee Surv. Quart. 2012, 31, 1-20. [CrossRef]

11. Demeny, P. Europe's two demographic crises: The visible and the unrecognized. Pop. Dev. Rev. 2016, 42, 111-120. [CrossRef]

12. Moreno-Lax, V. The EU Humanitarian Border and the Securitization of Human Rights: The 'Rescue-ThroughInterdiction/Rescue-Without-Protection' Paradigm. J. Common Mark.Stud. 2018, 56, 119-140. [CrossRef]

13. Brekke, J.P.; Brochmann, G. Stuck in transit: Secondary migration of asylum seekers in Europe, national differences, and the Dublin regulation. J. Refug. Stud. 2015, 28, 145-162. [CrossRef]

14. Nagy, A.I.; Dornfeld, L.L. Developments of certain EU fair trial measures as part of the Stockholm Programme. Zbornik Radova 2017, 51, 865. [CrossRef]

15. Billet, C. EC readmission agreements: A prime instrument of the external dimension of the EU's fight against irregular immigration. An assessment after ten years of practice. Eur. J. Migr. Law 2010, 12, 45-79. [CrossRef]

16. Molnár, T. EU migration law shaping international migration law in the field of expulsion of aliens-the case of the ILC draft articles. Hung. J. Legal Stud. 2017, 58, 237-260.

17. Schoukens, P.; Buttiens, S. Social protection of non-removable rejected asylum-seekers in the EU: A legal assessment. Eur. J. Soc. Secur. 2017, 19, 313-334. [CrossRef]

18. Salmerón-Manzano, E.; Manzano-Agugliaro, F. Worldwide scientific production indexed by Scopus on Labour Relations. Publications 2017, 5, 25. [CrossRef]

19. Garrido-Cardenas, J.A.; Mesa-Valle, C.; Manzano-Agugliaro, F. Trends in plant research using molecular markers. Planta 2018, 247, 543-557. [CrossRef]

20. Gimenez, E.; Manzano-Agugliaro, F. DNA Damage Repair System in Plants: A Worldwide Research Update. Genes 2017, 8, 299. [CrossRef]

21. Salmeron-Manzano, E.; Manzano-Agugliaro, F. The Electric Bicycle: Worldwide Research Trends. Energies 2018, 11, 1894. [CrossRef]

22. Aznar-Sánchez, J.A.; Belmonte-Ureña, L.J.; Velasco-Muñoz, J.F.; Manzano-Agugliaro, F. Economic analysis of sustainable water use: A review of worldwide research. J. Clean. Product. 2018, 198, 1120-1132. [CrossRef]

23. Van Eck, N.J.; Waltman, L. Software survey: VOSviewer, a computer program for bibliometric mapping. Scientometrics 2010, 84, 523-538. [CrossRef] [PubMed]

24. Padilla, F.M.; Gallardo, M.; Manzano-Agugliaro, F. Global trends in nitrate leaching research in the 1960-2017 period. Sci. Total Environ. 2018, 643, 400-413. [CrossRef] [PubMed]

25. EU. European Asylum Support Office. 2013. Available online: http://www.scepnetwork.org/images/21/ 262.pdf (accessed on 15 September 2018).

26. Chavez, L.; Menjívar, C. Children without borders: A mapping of the literature on unaccompanied migrant children to the United States. Migr. Int. 2017, 5, 71-111.

27. Doering-White, J. The shifting boundaries of "best interest": Sheltering unaccompanied Central American minors in transit through Mexico. Child. Youth Serv. Rev. 2018, 92, 39-47. [CrossRef]

28. Carling, J. Migration control and migrant fatalities at the Spanish-African borders. Int. Migr. Rev. 2007, 41, 316-343. [CrossRef]

29. Wood, T.; McAdam, J., III. Australian Asylum Policy all at Sea: An analysis of Plaintiff M70/2011 v Minister for Immigration and Citizenship and the Australia-Malaysia Arrangement. Int. Comp. Law Quart. 2012, 61, 274-300. [CrossRef]

30. Evenhuis, M. Child-proofing asylum: Separated children and refugee decision making in Australia. Int. J. Refug. Law 2013, 25, 535-573. [CrossRef]

31. Schmeling, A.; Reisinger, W.; Geserick, G.; Olze, A. Age estimation of unaccompanied minors: Part I. General considerations. Forensic Sci. Int. 2006, 159, 616. [CrossRef] 
32. Crea, T.M.; Lopez, A.; Hasson, R.G.; Evans, K.; Palleschi, C.; Underwood, D. Unaccompanied immigrant children in long term foster care: Identifying needs and best practices from a child welfare perspective. Child. Youth Serv. Rev. 2018, 92, 56-64. [CrossRef]

33. Thommessen, S.A.O.T.; Corcoran, P.; Todd, B.K. Voices rarely heard: Personal construct assessments of Sub-Saharan unaccompanied asylum-seeking and refugee youth in England. Child. Youth Serv. Rev. 2017, 81, 293-300. [CrossRef]

34. López, J.M. La necesidad de un protocolo común en Europa sobre la detención de menores extranjeros no acompañados. Revista de Derecho Comunitario Europeo 2013, 17, 1061-1090.

35. Derluyn, I.; Broekaert, E. Different perspectives on emotional and behavioural problems in unaccompanied refugee children and adolescents. Ethn. Health 2007, 12, 141-162. [CrossRef] [PubMed]

36. Ní Raghallaigh, M. The causes of mistrust amongst asylum seekers and refugees: Insights from research with unaccompanied asylum-seeking minors living in the Republic of Ireland. J. Refug. Stud. 2013, 27, 82-100. [CrossRef]

37. Goodman, J.H. Coping with trauma and hardship among unaccompanied refugee youths from Sudan. Qual. Health Res. 2004, 14, 1177-1196. [CrossRef]

38. Vervliet, M.; De Mol, J.; Broekaert, E.; Derluyn, I. 'That I Live, that's Because of Her': Intersectionality as Framework for Unaccompanied Refugee Mothers. Br. J. Soc. Work 2013, 44, 2023-2041. [CrossRef]

39. De Graeve, K.; Bex, C. Caringscapes and belonging: An intersectional analysis of care relationships of unaccompanied minors in Belgium. Child. Geogr. 2017, 15, 80-92. [CrossRef]

40. Boothby, N. Reuniting Unaccompanied Children and Families in Mozambique: An Effort to Link Networks of Community Volunteers to a National Programme. J. Soc. Dev. Africa 1993, 8, 11-22.

41. Bemak, F.; Timm, J. Case study of an adolescent Cambodian refugee: A clinical, developmental and cultural perspective. Int. J. Adv. Counsell. 1994, 17, 47-58. [CrossRef]

42. Wolff, P.H.; Tesfai, B.; Egasso, H.; Aradomt, T. The orphans of Eritrea: A comparison study. J. Child Psychol. Psychiatry 1995, 36, 633-644. [CrossRef]

43. Mukakayumba, E. Rwanda: Violence committed against women in the context of generalized armed conflict. Rech. Fem. 1995, 8, 145-154.

44. Fazel, M.; Stein, A. The mental health of refugee children. Arch. Dis. Child. 2002, 87, 366-370. [CrossRef]

45. Lustig, S.L.; Kia-Keating, M.; Knight, W.G.; Geltman, P.; Ellis, H.; Kinzie, J.D.; Saxe, G.N. Review of child and adolescent refugee mental health. J. Am. Acad. Child Adol. Psychiatry 2004, 43, 24-36. [CrossRef] [PubMed]

46. Bhabha, J.; Young, W. Not adults in miniature: Unaccompanied child asylum seekers and the new US guidelines. Int. J. Refug. Law 1999, 11, 84. [CrossRef]

47. Olze, A.; Reisinger, W.; Geserick, G.; Schmeling, A. Age estimation of unaccompanied minors: Part II. Dental aspects. Forensic Sci. Int. 2006, 159, S65-S67. [CrossRef] [PubMed]

48. Nuzzolese, E.; Di Vella, G. Forensic dental investigations and age assessment of asylum seekers. Int. Dent. J. 2008, 58, 122-126. [CrossRef] [PubMed]

49. United Nations. Convention on the Rights of the Child. Adopted and Opened for Signature, Ratification and Accession by General Assembly Resolution 44/25 of 20 November 1989, Entry into Force 2 September 1990, in Accordance with Article 49. Available online: http:/ /www.ohchr.org/EN/ProfessionalInterest/ Pages/CRC.aspx (accessed on 15 September 2018).

50. Kenny, M.A.; Loughry, M. Addressing the limitations of age determination for unaccompanied minors: A way forward. Child. Youth Serv. Rev. 2018, 92, 15-21. [CrossRef]

51. Thevissen, P.; Kvaal, S.I.; Dierickx, K.; Willems, G. Ethics in age estimation of unaccompanied minors. J. Forensic Odonto-Stomatol. 2012, 30, 85-102.

52. Rania, N.; Migliorini, L.; Sclavo, E.; Cardinali, P.; Lotti, A. Unaccompanied migrant adolescents in the Italian context: Tailored educational interventions and acculturation stress. Child Youth Serv. 2014, 35, 292-315.

53. Bravo, A.; Santos-González, I. Asylum-seeking children in Spain: Needs and intervention models. Psychosoc. Int. 2017, 26, 55-62.

(C) 2018 by the authors. Licensee MDPI, Basel, Switzerland. This article is an open access article distributed under the terms and conditions of the Creative Commons Attribution (CC BY) license (http:/ / creativecommons.org/licenses/by/4.0/). 